\title{
Tourism income and economic growth in Greece: empirical evidence from their cyclical components
}

\author{
BRUNO EECKELS \\ Les Roches, International School of Hotel Management, Bluche, Switzerland. \\ E-mail: bruno.eeckels@lesroches.edu.
}

GEORGE FILIS

Department of Economics, Portsmouth Business School, University of Portsmouth, Richmond Building, Portland Street, Portsmouth P01 3DE, UK. E-mail: george.filis@port.ac.uk. (Corresponding author.)

\section{COSTAS LEON}

César Ritz Colleges, Löwenstrasse 16, 6004 Lucerne, Switzerland. E-mail: costas.leon@ritz.edu.

This paper examines the relationship between the cyclical components of Greek GDP and international tourism income for Greece for the period 1976-2004. Using spectral analysis the authors find that cyclical fluctuations of GDP have a length of about nine years and that international tourism income has a cycle of about seven years. The volatility of tourism income is more than eight times the volatility of the Greek GDP cycle. VAR analysis shows that the cyclical component of tourism income is significantly influencing the cyclical component of GDP in Greece. The findings support the tourism-led economic growth hypothesis and are of particular interest and importance to policy makers, financial analysts and investors dealing with the Greek tourism industry.

Keywords: tourism income; GDP; business cycle; spectral analysis; VAR; Greece

JEL classification: C32; L83; O40

The authors would like to thank Professor Stephen Wanhill, the Editor of Tourism Economics. The helpful comments of the referees are gratefully acknowledged: they paved the way for significant improvement of our manuscript. Finally, we thank Professor Philip Hardwick for his valuable comments. The authors are entirely responsible for any remaining errors and deficiencies. 
This study examines the relationship between the cyclical components of tourism income and economic growth in Greece. This relationship has been studied significantly since the 1960s. Papers by McKinnon (1964), Elliott-Jones (1971), Bryden (1973) and Belisle and Hoy (1980) were among the first to explore it. Specifically, McKinnon (1964), in his seminal paper, argued that tourism generated foreign exchange which could be used to finance imports, contributing to economic growth. This was the first study to offer support to the hypothesis of tourism-led economic growth; that is, a unidirectional causality running from the tourism industry to economic growth. However, the relationship between tourism and economic growth received increased attention after the seminal works of Hazari and Sgrò (1995), Lanza and Pigliaru (1995) and Copeland (1991). Authors who subsequently studied this relationship include Durbarry (2004), Dritsakis (2004), Narayan (2004), Lanza et al (2003), Balaguer and Cantavella-Jordá (2002), Sharpley and Telfer (2002), Shan and Wilson (2001), Clancy (1999), Page (1999) and Brohman (1996), among others. Support for the economic-driven tourism growth (EDTG) hypothesis can be found in Lanza et al (2003) and Narayan (2004), whereas Shan and Wilson (2001) and Cortés-Jiménez and Pulina (2006) argue in support of the tourismled economic growth (TLEG) hypothesis. In addition, other studies demonstrate that there is a bidirectional relationship between the two (see Dritsakis, 2004, and Durbarry, 2004, among others).

Greece was chosen for this study as its tourism industry represents an important sector of the economy in respect to income source (Dritsakis, 2004). In 2007, tourism income accounted for $18 \%$ of the Greek Gross Domestic Product (www.investingreece.gov.gr). A decade earlier the proportion was $17 \%$ (Pavlopoulos, 1999), but in 2005 it was 15\% (Papanikos, 2005). That decrease was mainly influenced by the rise observed in tourism income in 2004 due to the Athens Olympic Games. The Greek Ministry of Economy and Finance estimated that in 2006 tourism accounted for about 16.5\% of the total Greek employment - roughly 700,000 jobs. Currently, the tourism industry employs about 900,000 people (www.investingreece.gov.gr). In addition, tourism is seen as an important means for the economic development of the Greek periphery (Hellenic Republic, Ministry of Economy and Finance, 2006).

The overwhelming majority of the aforementioned studies focus on the longrun relationship between tourism and the economic development of a country. However, the short-run relationship between the two series, as expressed by the cyclical fluctuations in economic activity, has not been fully examined. Cyclical fluctuations are waves with a period of between 1.5 and 8 years, although a period of even 12 years can also be observed. It is commonly acknowledged that, apart from long-run trends, aggregate economic time series are subject to cyclical fluctuations which, in general, differ in terms of convergence pattern, synchronicity with other key macroeconomic variables, persistence and duration. Hence, in this study we investigate the relationship between the cyclical components of tourism income and economic growth by means of spectral analysis and VAR modelling. The isolation of the cyclical components can provide additional evidence on the short-run relationship of the two series, which can be used by policy makers.

We use business cycles as they represent fluctuations around the long-run 
economic growth; that is, they are components of the short-run fluctuations. Burns and Mitchell (1946, p 3) define business cycle as follows:

'A cycle consists of expansions occurring at about the same time in many economic activities, followed by similarly general recessions, contractions, and revivals which merge into the expansion phase of the next cycle; this sequence of changes is recurrent but not periodic; in duration, business cycles vary from more than one year to ten or twelve years; they are not divisible into shorter cycles of similar character with amplitudes approximating their own.'

Business cycles, though, are not the only short-run fluctuations around the long-run trend of a series: other short-run fluctuations, for example, are seasonality and unpredicted noise. However, business cycles exhibit significantly different features from the other short-run fluctuations, as they exhibit a recurrent motion with no fixed length or amplitude and are common in most macroeconomic variables. Thus, it is important to study the different behaviour of the economy or economic sectors during expansions and contractions (that is, in the different phases of the business cycle).

Business cycle stabilization efforts have increased significantly since the Second World War (Diebold and Rudebusch, 2001). Furthermore, Rudebusch and Svensson (1999) support the view that forecasting business cycles is an important tool in the formulation of successful policies.

In particular, tourism and economic cycles can be linked using basic microeconomic theory, suggesting that households will be willing to spend more on luxury goods if their disposable income increases. Considering that tourism travel is regarded as being a luxury good (see Wong, 1997), we could argue that tourism travel could be affected by economic boom/bust periods, which positively/negatively influence disposable income (Wong, 1997).

Gouveia and Rodrigues (2005) used a non-parametric method proposed by Harding and Pagan (2003) to date tourism growth cycles. On the basis of cycle indicator function, they found a greater degree of cycle synchronization of tourism demand among the countries under examination (the UK, Germany, the Netherlands and Portugal) than that observed at the economic cycle level and, using a recursive correlation coefficient, concluded that this degree of cycle synchronization had increased over the years.

Additional research in the area of tourism and economic cycles can be found in Guizzardi and Mazzocchi (2010), who conclude that tourism cycles are significantly affected by economic cycles, with some lag. Specifically, they argue that tourism cycles lag the general economic activity cycles due to the 'substitution effects between types of destinations and lags between decision making and the actual holiday' (Guizzardi and Mazzocchi, 2010, p 1).

Overall, Song and Li (2008) specifically point out the lack of studies on the link between tourism and economic cycles. This paper therefore contributes to the existing literature as no previous study has been conducted regarding the interrelationship between the cyclical fluctuations of tourism income and economic growth and their possible interactions in Greece. We further contribute to this issue by examining the statistical properties of the cyclical components of Greek tourism income and Greek GDP in terms of 
synchronization, duration and persistence, and the transmission mechanism of these two variables.

The rest of the paper is organized as follows. The next section reviews the literature related to tourism income and economic growth. The methodology and data used are then presented. Subsequently, the empirical results are analysed, and finally we offer our conclusions and highlight the policy implications.

\section{The relationship between tourism income and economic growth}

The contribution of the tourism industry (in terms of income generation, employment, etc) can be very significant for the economy of a country (Armstrong and Read, 2000). Hence, the development of tourism has usually been considered as a positive contribution to economic growth (Khan et al, 1995; Lee and Kwon, 1995).

Furthermore, Dritsakis (2004) proposes the view that the contribution of tourism to a country's economy is multifaceted, affecting its exchange rate, as well as different sectors of the economy such as the employment sector (by reducing the propensity to emigrate), the business sector (as it has to develop in order to meet the increasing tourist market), the income sector (in its contribution to aggregate income and the importance of the multiplier effect), the cultural sector (by improving the living standards of the people) and the fiscal sector (as tourism activities yield income to the public sector).

More specifically, Dritsakis (2004), studying Greece for the period 19602000 , demonstrated that in the long-run tourism earnings and real effective exchange rate had a positive effect on gross domestic product. When applying a Granger causality test on the error correction model, he observed that there is a bidirectional Granger causal relationship between international tourism earnings and economic growth, and a unidirectional Granger causality between the real exchange rate and economic growth. The author stressed the necessity of public intervention in order to act on both the demand and the supply sides of tourism activity in Greece.

Numerous studies have shown that tourism income can lead to economic growth via increased employment, income and tax revenues (Croes and Vanegas, 2006; Vanegas and Croes, 2003; Sugiyarto et al, 2002; Page, 1999; Uysal and Gitelson, 1994; West, 1993; Khan et al, 1990). These findings tend to support the tourism-led economic growth (TLEG) hypothesis.

Balaguer and Cantavella-Jordá (2002), in order to assess the role of tourism in the economic growth of Spain, developed a model including tourism earnings, GDP and real effective exchange rate (the last variable being a proxy for external competitiveness) for 1975-97. Using Johansen cointegration techniques, they found one cointegrating vector among these three variables, indicating that tourism positively affected Spain's economic growth in the longrun. Furthermore, applying a Granger causality test, they observed that tourism affected Spain's economic growth unidirectionally.

Furthermore, tourism enhances efficiency as local firms have to compete with international organizations (Krueger, 1980; Bhagwati and Srinivasan, 1979). It 
also facilitates the exploitation of economy of scales for local firms (Helpman and Krugman, 1985).

Researching the impact of tourism on the Mauritian economy, Durbarry (2004) assessed the relationship between exports in general and GDP for 195299. He found one cointegration vector, implying that exports affected Mauritius's growth unidirectionally. Decomposing exports into various sectors, the author observed that, although sugar and manufacturing exports had contributed significantly to growth, tourism had a major impact on the Mauritian economy.

Similarly, Carrera et al (2008) suggested that the TLEG hypothesis held for the Mexican economy, using a cointegration analysis. Impulse responses showed that tourism income initially caused a shortfall in the economy but then exhibited a significant positive effect on economic growth.

One of the more recent studies in the area was developed by Cortés-Jiménez et al (2009). They used cointegration and causality tests to examine the Italian and the Spanish economies, using data from 1954 to 2000 and 1964 to 2000, respectively. They concluded that tourism income led to economic growth. In addition, Zortuk (2009) examined this relationship in Turkey for 1990 Q1 to 2008 Q3, using a Granger causality test. The study's evidence supported the TLEG hypothesis. Croes and Vanegas (2008) painted the same picture in their study on the relationship between tourism, economic development and poverty in Nicaragua. Using cointegration and causality tests, they found evidence suggesting that tourism development had a positive impact on the economy, mainly due to the reduction in poverty.

Other recent studies that have found evidence in favour of the TLEG hypothesis include Katircioglu (2009), Carrera et al (2008), Fayissa et al (2007), Noriko and Motosugu (2007), Louca (2006), Cortés-Jiménez and Pulina (2006), Kim et al (2006), Gunduz and Hatemi (2005), Soukiazis and Proença (2008), Eugenio-Martín et al (2004), Shan and Wilson (2001) and Gani (1998).

There are studies, however, which reported a bidirectional causality between tourism developments and economic growth (see Lee and Chang, 2008; CortésJiménez and Pulina, 2006; Durbarry, 2004; Lanza et al, 2003; Shan and Wilson, 2001). These studies offer support for both the TLEG and the economic-driven tourism growth (EDTG) hypotheses. ${ }^{1}$

Nowak et al (2007) suggested that tourism income, as an income stream in foreign currency, could be used to finance imports of capital goods, which in turn could lead to increased domestic investment and consumption, and thus to economic growth. Such findings support the tourism-capital goods importsgrowth (TKIG) hypothesis.

Chen and Chiou-Wei (2009) used a different approach to study the relationship between tourism expansion and economic growth in Taiwan and South Korea; that of an EGARCH-M model. They concluded that the TLEG hypothesis held for Taiwan, whereas there was bidirectional causality in the case of South Korea.

We should not lose sight of the fact though that the TLEG hypothesis is expected to hold only when the overall economy is linked to tourism developments, in the form of spillovers and other externalities, as Marin (1992) suggested.

The evidence that tourism influences the long-run development of a country 
is not universal. For example, Oh (2005) using a similar approach to Durbarry (2004), could not find evidence of long-run equilibrium between tourism earnings and economic growth for Korea. Additionally, the results from the Granger causality test suggested a one-way causal relationship of growth-led tourism for Korea, with the causality running from GDP to tourism. Other studies that second this finding include those of Narayan (2004) and Lanza et al (2003).

The above studies are based mainly on econometric techniques such as cointegration and error correction models, trying to identify the long-run relationship between economic growth and tourism. However, for developing countries, given the low quality of the data and their small length, computable general equilibrium (CGE) models may be a more efficient alternative. In this line of research, Wyer et al (2003) argue that the advantage of this technique over the more traditional general equilibrium models such as input-output tables, lies in the fact that a CGE model includes a realistic set of economywide constraints (since it can incorporate economic theory-driven assumptions, neoclassical or structuralist) and, therefore, that the effects of tourism growth on a destination cannot be anticipated a priori. Similarly, Narayan (2004) used a CGE model to research the impact of an increase in tourism receipts on the other sectors of Fiji's economy, concluding that the increase in tourism and nontraditional exports outweighed the fall in traditional exports and that tourism made a positive contribution to Fiji's economy, both in terms of GDP and national welfare. Based on the same modelling techniques, Sugiyarto et al (2003), assessing the impacts of globalization and tourism on the Indonesian economy, found that tourism growth amplified the positive effects of globalization and lessened its adverse effects. More specifically, the authors observed that production increased and welfare improved, while adverse effects on government deficits and the trade balance were reduced.

\section{Statistical methodology, data description and cyclical components}

\section{Statistical methodology}

The study initially reports some preliminary findings, using descriptive statistics and spectral analysis. The latter will be used for the identification of the dominant cycle of C_GDP and C_TI, where C_GDP is the cyclical component of GDP and $C_{-}$TI is the cyclical component of tourism income (TI).

In the main, the paper uses a VAR model to assess the relationship between cyclical components of tourism income and GDP in Greece. The VAR model will also assist in the identification of the transmission mechanism of stochastic shocks to our series.

Spectral analysis. Using spectral analysis we are able to decompose a time series in different periodicities (see Baxter and King, 1999; Granger and Watson, 1984; Granger and Hatanaka, 1964). Given a stationary time series $y_{t}$ with autocovariance function $\chi(k)$, the spectrum $f_{y}(\omega)$ is given by: 
$f_{y}(\omega)=\frac{1}{2 \pi} \int_{\infty}^{\infty} \gamma(k) e^{-i k \omega} d k$

with $-\pi \leq \omega \leq \pi$. $\omega$ is the radian frequency, $k$ the lag value from the autocovariance function, and $i$ the imaginary unit. In practice, because the samples are finite, an algorithm based on the discrete Fourier transform (DFT) is implemented. The spectrum function is used to map each frequency to the intensity of the frequency. The higher explanatory power among all frequencies can be found in these few frequencies that dominate the spectrum. Hence, the important cyclical movements of the series can be adequately captured by the superposition of these few dominant frequencies. A detailed explanation of the spectral analysis can be found in Filis et al (2010), Leon and Eeckels (2009) and Filis and Leon (2006).

VAR framework. Furthermore, we use a standard VAR model, using the Johansen procedure (Johansen, 1988; Johansen and Juselius, 1990, 1992 and 1994), which assists in the identification of the transmission mechanism of stochastic shocks to the cyclical components of GDP and tourism income, in terms of the convergence pattern (monotonic/oscillating). The VAR model will also be used to estimate the time required for the convergence to take place. A VAR model takes the following general form:

$$
\mathbf{y}_{t}=c+\mathbf{A}_{1} \mathbf{y}_{t-1}+\mathbf{A}_{2} \mathbf{y}_{t-2}+\ldots+\mathbf{A}_{n} \mathbf{y}_{t-n}+\mathbf{u}_{t}
$$

where $\mathbf{y}_{t}$ is a $m \times 1$ vector of endogenous variables, $\mathbf{A}_{i} m \times m$ coefficient matrices, $\mathbf{u}_{t}$ a $m \times 1$ vector of stochastic disturbances, assumed to be white noise processes. In our paper $m=2$. A detailed explanation of the VAR model can be found in Filis and Leon (2006), Favero (2001) and Enders (1995).

\section{Data description}

The study uses yearly data series, from 1976 to 2004, of the Greek Gross Domestic Product (GDP) and tourism income from foreign tourists (TI). Both variables are expressed in euros and in constant 2000 prices. The data were retrieved from International Financial Statistics (IFS) and the World Tourism Organization. We denote our series in levels as GDP and TI. All variables are expressed in logarithms.

The choice of our data was primarily driven by availability. It would be worth examining the link between the cyclical fluctuations of tourism income and economic growth using higher frequency data (such as quarterly and/or monthly data). It is expected that seasonally adjusted quarterly data would not alter the spectral properties of the time series under consideration.

\section{Cyclical components}

A widely applied method to extract the cyclical component of a series $y_{t}$ is to decompose it as follows:

$$
y_{t}=T r_{t}+S e_{t}+C_{t}+u_{t}
$$


where $\operatorname{Tr}_{t}, S e_{t}, C_{t}, u_{t}$ are the long-run trend, the seasonal component, the cyclical and the irregular (noise) components of the series, respectively.

Seasonality does not exist since we have annual data. We also assume that noise takes an average value of zero, so, on average, Cyclical component + noise = Actual data - Estimated trend. The long-run trends have been estimated with the Hodrick-Prescott (HP) filter (Hodrick and Prescott, 1997) with smoothing parameter $\lambda=100$, which is appropriate for yearly macroeconomic time series (Ewing and Thomson, 2007; Inklaar and de Haan, 2001; Dickerson et al, 1998; Christodoulakis et al, 1995). Given that the HP filter has been applied in the variables' logs, then the difference Actual data - Estimated trend expresses, approximately, the percentage change of each observation at time $t$ from the estimated trend at the same time. The cyclical components of the variables are denoted as C_GDP for GDP and C_TI for tourism income.

\section{Preliminary results}

\section{Descriptive statistics}

We start our preliminary results with the long-run developments of the variables (Figure 1). Figure 2 presents the cyclical components of our series (that is, C_GDP and C_TI).

Starting from 1978, we observe that for both series a cycle starts with duration of about nine years and seven years for C_GDP and C_TI, respectively. The first cycle for C_GDP ends in 1986-87, whereas for tourism income the first cycle ends in 1985. The same pattern is observed until the end of the period under examination, 2004. However, the amplitude is significantly different: C_TI has a higher amplitude than C_GDP. This is expected as tourism income exhibits greater volatility (standard deviation is used as a proxy

GDP

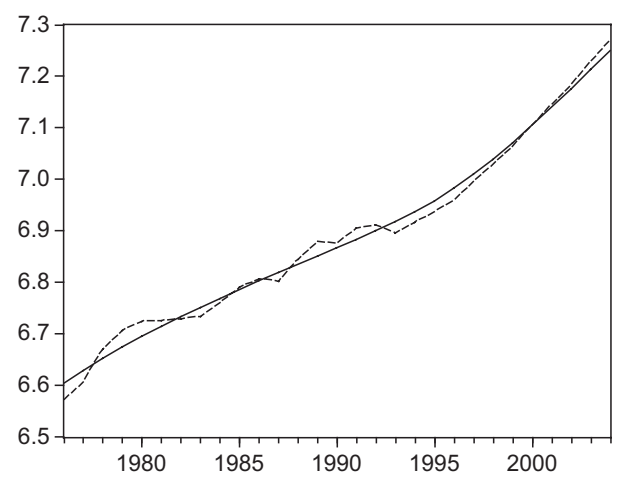

TI

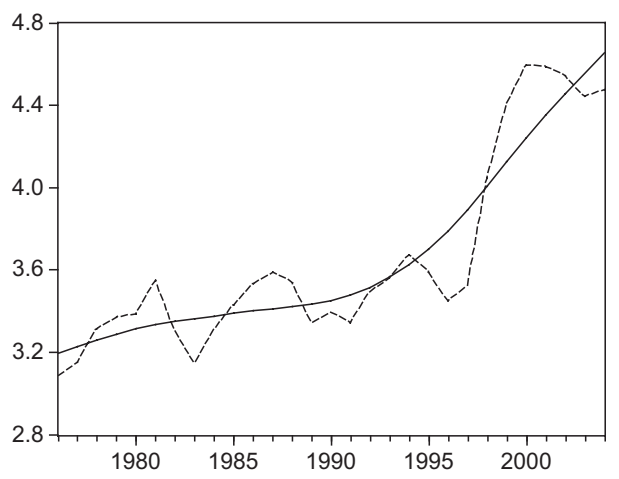

Figure 1. Long-run trends of GDP and TI.

Note: GDP, TI: logarithms of GDP and tourism income. 
C_GDP

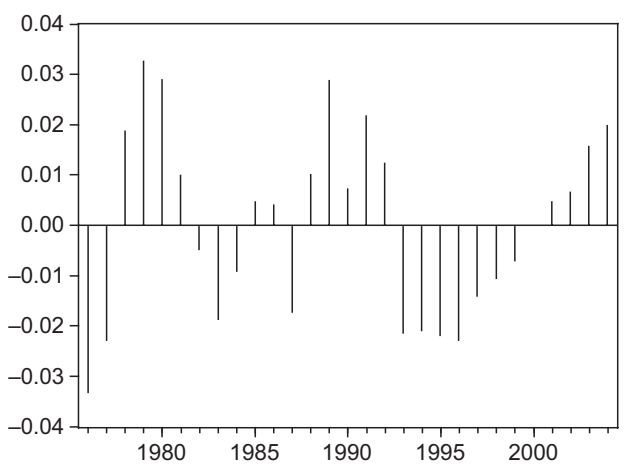

C_TI

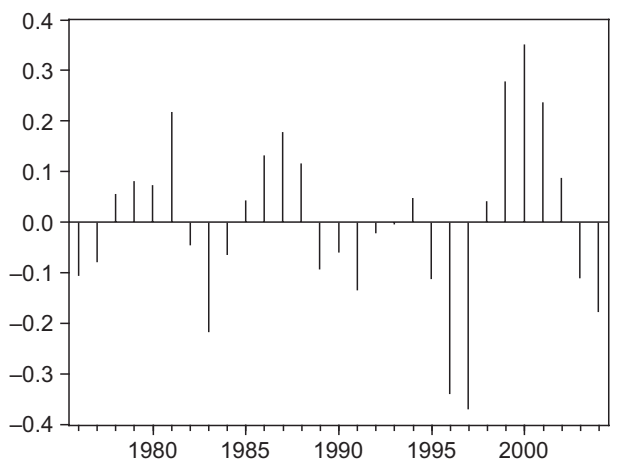

Figure 2. Cyclical components of GDP and TI.

Note: C_GDP, C_TI denote the cyclical component of GDP and tourism income. Smoothing in the two diagrams is done exclusively for illustration purposes and does not participate in the calculations.

Table 1. Descriptive statistics of C_GDP and C_TI.

\begin{tabular}{lcc}
\hline & C_GDP & C_TI \\
Mean & $2.90 \mathrm{E}-14$ & $1.58 \mathrm{E}-14$ \\
Median & 0.003915 & -0.00127 \\
Maximum & 0.032649 & 0.350456 \\
Minimum & -0.03323 & -0.36842 \\
Std dev & 0.018232 & 0.168701 \\
Skewness & 0.052838 & -0.10548 \\
Kurtosis & 1.933853 & 2.894452 \\
Jarque-Bera & 1.386969 & 0.067236 \\
\hline
\end{tabular}

of amplitude of the oscillation) than GDP (Table 1). Indeed, the standard deviation for GDP is $2 \%$, whereas for tourism income it is $17 \%$ - more than eight times higher. This may constitute evidence of the volatile nature of the tourism sector. All series are normally distributed, as is evident from the JarqueBera normality test.

\section{Spectral analysis findings}

We proceed now to the length of the cycles which are estimated formally using spectral analysis. ${ }^{2}$ The periodogram's maximum value corresponds to the estimated dominant length of the cycle (Tables 2 and 3). The dominant length of the C_GDP is 9.3 years and for the C_TI it is 7 years. This is relatively in accordance with Varelas and Kaskarelis's (1996) findings, who have estimated a dominant cycle for GDP in Greece of about 8.3 years. In addition, the length of the second most dominant cycle is 14 years for both series. 
Table 2. Spectral densities of C_GDP.

\begin{tabular}{rrrrrrr}
\hline & Frequency & Period & Cosine & Sine & Periodogram & Density \\
0 & 0.000000 & & -0.001413 & 0.000000 & 0.000028 & 0.000534 \\
1 & 0.035714 & 28.00000 & 0.000420 & 0.008086 & 0.000918 & 0.000806 \\
2 & 0.071429 & 14.00000 & 0.008844 & 0.000594 & 0.001100 & 0.001350 \\
3 & $\mathbf{0 . 1 0 7 1 4 3}$ & 9.33333 & -0.013474 & $\mathbf{0 . 0 0 1 5 6 7}$ & $\mathbf{0 . 0 0 2 5 7 6}$ & $\mathbf{0 . 0 0 1 6 1 7}$ \\
\hline
\end{tabular}

Note: The row in bold type indicates the dominant cycle.

Table 3. Spectral densities of C_TI.

\begin{tabular}{rrrrrrr}
\hline & Frequency & Period & Cosine & Sine & Periodogram & Density \\
0 & 0.000000 & & 0.012611 & 0.000000 & 0.002227 & 0.025658 \\
1 & 0.035714 & 28.00000 & 0.044864 & 0.024689 & 0.036712 & 0.044887 \\
2 & 0.071429 & 14.00000 & 0.019505 & -0.081137 & 0.097490 & 0.088549 \\
3 & 0.107143 & 9.33333 & -0.077525 & -0.016903 & 0.088141 & 0.165809 \\
4 & $\mathbf{0 . 1 4 2 8 5 7}$ & $\mathbf{7 . 0 0 0 0 0}$ & $-\mathbf{0 . 1 7 0 6 8 2}$ & $\mathbf{0 . 0 2 3 7 6 9}$ & $\mathbf{0 . 4 1 5 7 6 3}$ & $\mathbf{0 . 2 2 1 0 1 8}$ \\
\hline
\end{tabular}

Note: The row in bold type indicates the dominant cycle.

C_GDP

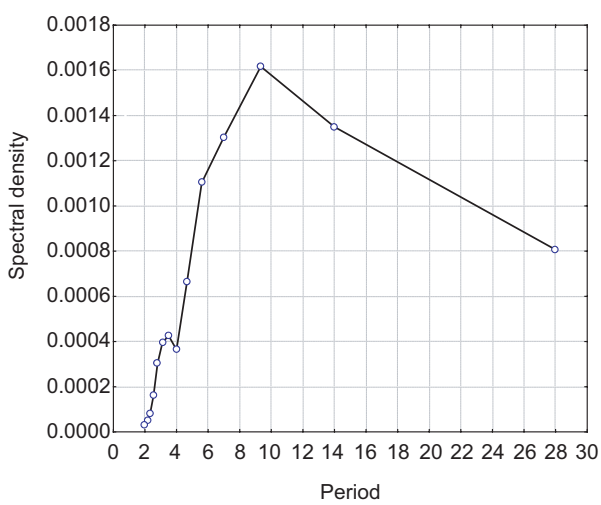

Figure 3. Spectral density estimates.

A graphical illustration of the cycles' length is presented in Figure 3, which depicts the spectral densities (in terms of time). The maximum values of the spectral densities correspond to the estimated dominant length of the cycles. The peaks of these graphs correspond to cycles of 9.3 years for the GDP and 7 years for the tourism income.

Having analysed some preliminary findings of our series, we now proceed to the estimation of the VAR model.

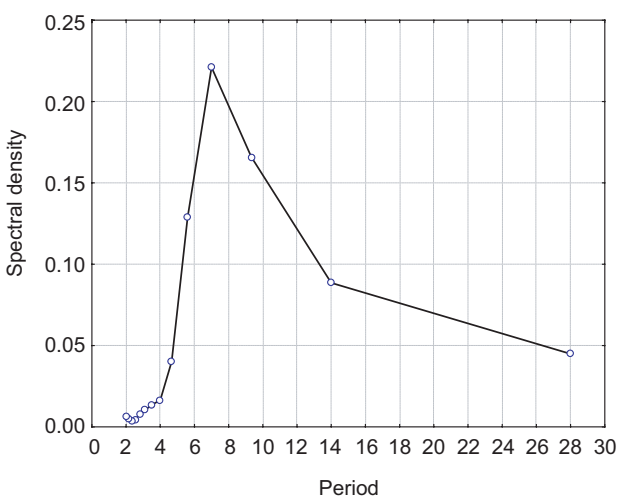

Period 


\section{Empirical findings}

\section{VAR results}

In order to proceed to the VAR model estimation it is necessary to examine the stationarity of the series and of the model. Table 4 shows that all series are stationary; that is, $\mathrm{I}(0)$.

Employing a Johansen cointegration approach ${ }^{3}$ (using trace statistic and maximum eigenvalues), we were able to conclude that the rank of matrix $\Pi=2$ (that is, full rank). Thus the VAR model is stationary. ${ }^{4}$ Furthermore, using AIC and SC criteria (the most commonly cited criteria), we were able to conclude that the order of the VAR model is four (see Table 5).

All tests suggested that we could proceed to the estimation of the VAR(4) model. ${ }^{5}$ Table 6 reports the findings from the VAR model. The main findings suggest that C_GDP is significantly influenced by its own lagged values. It is worth noting that the significant effect of the fourth lag of C_GDP is showing evidence that long memory exists in the GDP cycles in Greece. In addition, C_TI seems to exercise a significant positive effect on C_GDP, as the values of C_TI(-1) and C_TI(-4) suggest. On the other hand, C_GDP does not seem to affect $C_{-}$TI significantly. Overall, our findings provide support for the TLEG hypothesis rather than the EDTG hypothesis. Similar findings have been reported by other authors (see Katircioglu, 2009; Carrera et al, 2008; Fayissa et al, 2007; Noriko and Mototsugu, 2007; Louca, 2006; Cortés-Jiménez and Pulina, 2006; Croes and Vanegas, 2006; Vanegas and Croes, 2003; Sugiyarto et al, 2002). However, all these previous studies examine the long-run relationship between tourism income and economic growth, whereas in this study we

Table 4. Unit root test for C_GDP and C_TI.

\begin{tabular}{lll}
\hline & ADF & PP \\
C_GDP & $-2.861^{*}$ & $-3.022^{*}$ \\
C_TI & $-4.803^{*}$ & $-1.887^{* *}$ \\
\hline
\end{tabular}

Significant at $5 \%$ level; ${ }^{* *}$ Significant at $10 \%$ level.

Table 5. VAR lag order selection criteria.

\begin{tabular}{lcc}
\hline Lag & AIC & SC \\
0 & -6.006427 & -5.907688 \\
1 & -6.504118 & -6.207903 \\
2 & -6.909545 & -6.415852 \\
3 & -6.899334 & -6.208164 \\
4 & $-7.359740^{*}$ & $-6.471092^{*}$ \\
5 & -7.064043 & -5.977918 \\
6 & -6.864113 & -5.580511 \\
\hline
\end{tabular}

* Lag order selected by the criterion. 


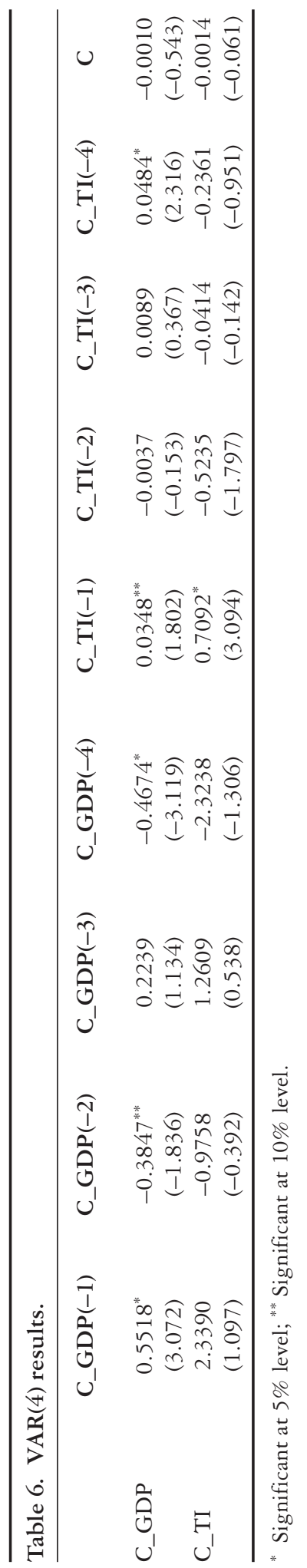


Responses to Cholesky One SD Innovations \pm 2 SE
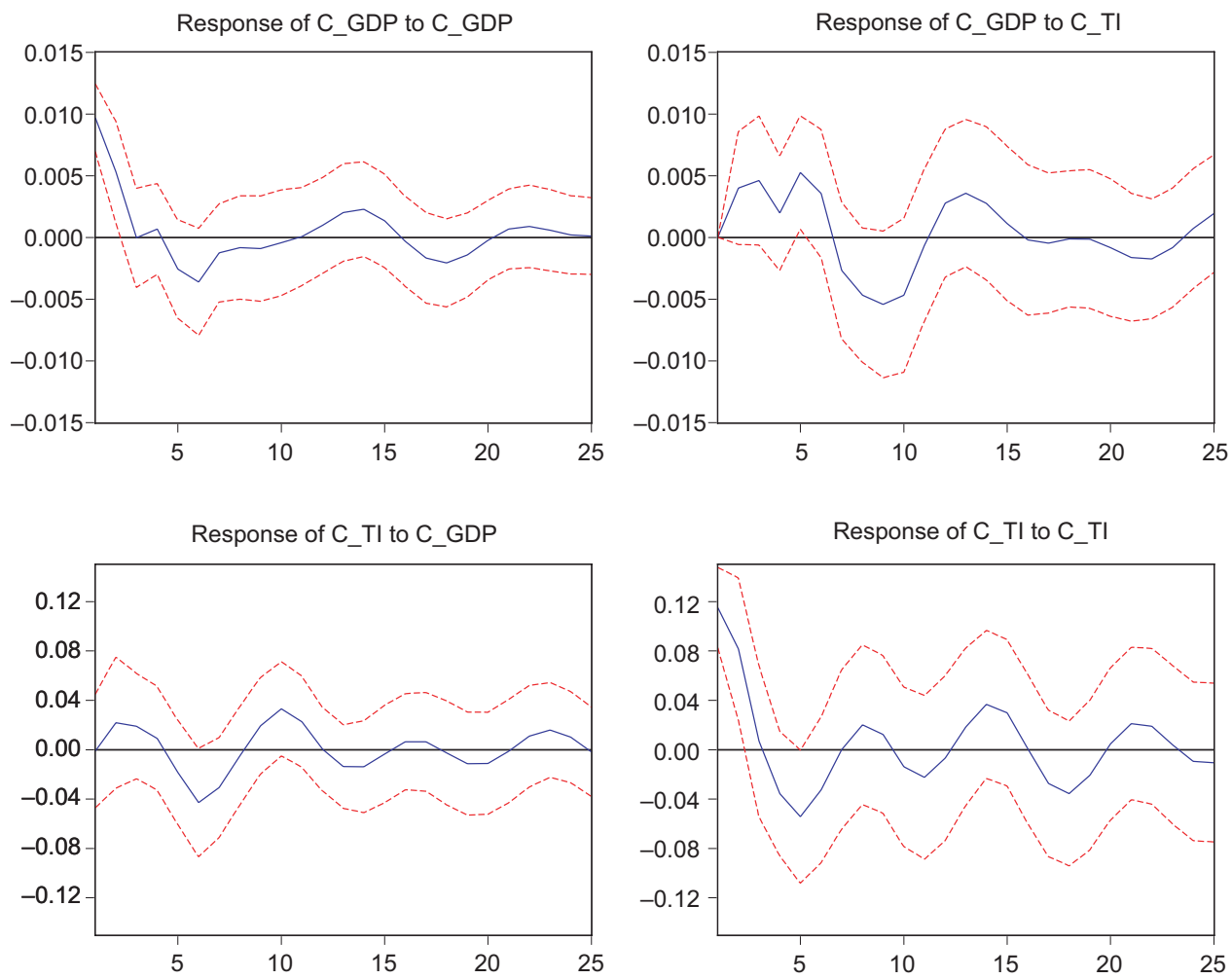

Figure 4. Impulse response function of C_GDP, C_TI.

Note: Transmission mechanisms (TMs) depicted by the impulse response function. TMs 1-2 refer to response of C_GDP to C_GDP, C_TI stochastic shocks. TMs 3-4 refer to response of C_TI to C_GDP, C_TI stochastic shocks.

investigate the short-run relationship. Our findings are somewhat different from those of Dritsakis (2004), who also studied Greece. Dritsakis (2004) argues that there is a bidirectional relationship between tourism income and economic growth, in the long run.

Furthermore, the purpose of the VAR model is mainly to examine the dynamic adjustments of each of the involved variables to exogenous stochastic structural shocks. We have chosen the Choleski decomposition - an identification scheme requiring, in the structural form of the VAR, all elements above the principal diagonal to be non-zero (in matrix $\mathbf{B}$ of the primitive system in the notation of Enders, 1995). ${ }^{6}$ The impulse response function is shown in Figure 4.

In Figure 4 we observe the response of the cyclical component of GDP and TI. We observe that the response of C_TI to C_GDP is much higher than the reverse. This may be explained on the basis that higher levels of tourism income result in higher economic growth (see Table 4). This is, in fact, an important 
Table 7. Impulse response function for C_GDP, C_TI.

Transmission mechanism

Response of C_GDP to C_GDP

Response of C_GDP to C_TI

Response of C_TI to C_GDP

Response of C_TI to C_TI
Pattern

$\begin{array}{ll}\text { Oscillating } & 26 \text { years } \\ \text { Oscillating } & 30 \text { years } \\ \text { Oscillating } & 29 \text { years } \\ \text { Oscillating } & 26 \text { years }\end{array}$

Note: Transmission mechanisms (TMs) 1-2 refer to response of C_GDP to C_GDP and C_TI stochastic shocks. TMs 3-4 refer to response of C_TI to C_GDP, C_TI stochastic shocks. Dynamic convergence refers to time required to achieve equilibrium in years.

reason to attract higher tourism income in Greece. In addition, the response of tourism income to its own shock is higher than is the response of GDP to its own shock. The convergence to equilibrium is not very different in length, since the transmission mechanisms adjustment requires 26-30 years to restore equilibrium (Table 7).

\section{Summary and policy implications}

In this paper we examine the relationship between the cyclical components of GDP and tourism income in Greece. In particular, we identify the transmission mechanism between the cyclical components of GDP and tourism income in Greece with data covering 1976-2004. Spectral analysis indicates that GDP has a cycle of 9.3 years and that tourism income has a cycle of 7 years. Moreover, the volatility of the tourism income cycle is more than three times the volatility of the GDP cycle.

To identify the transmission mechanism, we used a multi-equation framework by means of a VAR model. The VAR results suggest that the TLEG hypothesis holds for Greece, as C_TI is significantly influencing C_GDP. Furthermore, the converging path for C_GDP and C_TI is oscillating and requires several years to converge (about 26 years). These findings are in accordance with those of other studies which have shown the large influence of the tourism industry on economic development. We should not lose sight of the fact, however, that previous studies have examined the long-run relationship rather than the short-run relationship examined in this paper. For Greece, in particular, Dritsakis (2004) documented a bidirectional relationship between tourism income and economic growth. The difference in results may be ascribed to the fact that we examine only the cyclical components and not the long-run trends.

Our findings suggest that the TLEG hypothesis holds in the short-run for Greece. Thus the most practical approach for policy makers to follow is the one that paces the developments in tourism industry. In particular, specific fiscal policies should be considered which will enable the growth of the tourism industry in Greece. We should not disregard the fact that Greece is a country without a heavy industry to support its economy. However, tourism can act as the heavy industry of Greece and assist economic growth. Thus, the Investment 
Incentives Law, ratified by the Greek parliament in January 2011, is expected to provide an opportunity for growth in the tourism industry. In addition, the National Strategic Reference Framework (NSRF) for 2007-13, which establishes the broad priorities for EU Structural Funds Programmes in Greece, can further assist tourism development in Greece.

This research adds to the existing literature as it has a particular focus on the cyclical components of the series under examination. In addition, it examines a small economy in which the tourism industry is of major importance. The findings are of particular interest and importance to policy makers, financial analysts and investors dealing with the Greek economy and the Greek tourism industry.

Further research in the area could test for potential structural breaks in the relationship between the two series. In addition, more variables could be added to the model, such as unemployment, tax revenues, etc.

\section{Endnotes}

1. Collins and Tisdell (2004), though, studying outbound rather than inbound tourism in the Australian market, argued that GDP does not seem to influence outbound business travel, as opposed to business returns.

2. See, for example, Thalassinos (1991), Iacobucci (2003), Jenkins and Watts (1968).

3. Results can be provided on request.

4. Please refer to Harris (1995, p 79) for further explanation of the use of the Johansen cointegration approach as a multivariate generalization of the Dickey-Fuller test.

5. A further test on the VAR stationarity was performed, which examined the inverse roots of the characteristic polynomial. No root was found to lie outside the unit circle, which allowed us to conclude that the VAR(4) model satisfied the stability condition. Results can be provided on request.

6. We also experimented with different identification schemes, changing the ordering of the variables, and the results were qualitatively similar. This shows that there is no high degree of correlation between the reduced form errors.

\section{References}

Armstrong, H.W., and Read, R. (2000), 'Comparing the economic performance of dependent territories and sovereign microstates', Economic Development and Cultural Change, Vol 48, pp 285306.

Ballaguer, J., and Cantavella-Jordá, M. (2002), 'Tourism as a long-run economic growth factor: the Spanish case', Applied Economics, Vol 34, pp 877-884.

Baxter, M., and King, G.R. (1999), 'Measuring business cycles: approximate band-pass filters for economic time series', Review of Economic and Statistics, Vol 81, No 4, pp 575-593.

Belisle, F.J., and Hoy, D.R. (1980), 'The perceived impact of tourism by residents', Annals of Tourism Research, Vol 7, No 1, pp 83-101.

Bhagwati, J., and Srinivasan, T. (1979), 'Trade policy and development', in Dornbush, R., and Frenkel, J., eds, International Economic Policy: Theory and evidence, Johns Hopkins University Press, Baltimore, MD, pp 1-35.

Brohman, J. (1996), 'New directions in tourism for Third World development', Annals of Tourism Research, Vol 23, pp 48-70.

Bryden, J. (1973), Tourism and Development: a Case Study of the Commonwealth Caribbean, Cambridge University Press, Cambridge.

Burns, A.F., and Mitchell, W.C. (1946), Measuring Business Cycles, National Bureau of Economic Research, New York.

Carrera, E.J.S., Risso, W.A., and Brida, J.G. (2008), 'Tourism's impact on long-run Mexican economic growth', Economics Bulletin, Vol 23, No 21, pp 1-8.

Chen, C.F., and Chiou-Wei, S.Z. (2009), 'Tourism expansion, tourism uncertainty and economic growth: new evidence from Taiwan and Korea', Tourism Management, Vol 30, pp 812-818. 
Christodoulakis, N., Dimeli, S., and Kollintzas, T. (1995), 'Business cycles in the EC: idiosyncrasies and regularities', Economica, Vol 62, pp 1-27.

Clancy, M. (1999), 'Tourism and development: evidence from Mexico', Annals of Tourism Research, Vol 26, pp 1-20.

Collins, D., and Tisdell, C. (2004), 'Outbound business travel depends on business returns: Australian evidence', Australian Economic Papers, Vol 43, No 2, pp 192-207.

Copeland, B.R. (1991), 'Tourism, welfare, and de-industrialization in a small open economy', Economica, Vol 58, pp 515-529.

Cortés-Jiménez, I., and Pulina, M. (2006), 'A further step into the ELGH and TLGH for Spain and Italy’, FEEM Working Paper No 118.06, Fondazione Eni Enrico Mattei, Milan.

Cortés-Jiménez, I., Pulina, M., Prunera, C., and Artis, M. (2009), 'Tourism and exports as a means of growth', Working Paper, Research Institute of Applied Economics, University of Barcelona, Barcelona.

Croes, R., and Vanegas, M. (2006). 'Tourism and poverty alleviation: real promise or false premise?', paper presented at the Second International Conference on Tourism Economics, Palma de Mallorca, 18-20 May.

Croes, R., and Vanegas, M. (2008), 'Cointegration and causality between tourism and poverty reduction, Journal of Travel Research, Vol 47, pp 94-103.

Dickerson, A.P., Gibson, H.D., and Tsakalotos, E. (1998), 'Business cycle correspondence in the European Union', Empirica, Vol 25, pp 51-77.

Dickey, D.A., and Fuller, W.A. (1979), 'Distributions of the estimators for autoregressive time series with a unit root', Journal of the American Statistical Association, Vol 74, pp 427-431.

Diebold, F.X., and Rudebusch, D.G. (1996), 'Measuring business cycles: a modern perspective', Review of Economics and Statistics, Vol 78, No 1, pp 67-77.

Diebold, F.X., and Rudebusch, D.G. (2001), 'Five questions about business cycles', Economic Review, Federal Reserve Bank of San Francisco, pp 1-15.

Dritsakis, N. (2004), 'Tourism as a long-run economic growth factor: an empirical investigation for Greece using causality analysis', Tourism Economics, Vol 10, No 3, pp 305-316.

Durbarry, R. (2004), 'Tourism and economic growth: the case of Mauritius', Tourism Economics, Vol 10, No 4, pp 389-401.

Elliott-Jones, M. (1971), 'Exports and economic development: the West Indian case with special emphasis on tourism', PhD dissertation, University of Connecticut, Storrs, CT.

Enders, W. (1995), Applied Econometric Time Series, John Wiley \& Sons, New York.

Eugenio-Martín, J., Morales, N., and Scarpa, R. (2004), 'Tourism and economic growth in Latin American countries: a panel data approach', FEEM Working Paper No 2004.26, Fondazione Eni Enrico Mattei, Milan.

Ewing, B.T., and Thompson, M.A. (2007), 'Dynamic cyclical components of oil prices with industrial production, consumer prices, unemployment and stock prices', Energy Policy, Vol 35, pp 5535-5540.

Favero, C. (2001), Applied Macroeconometrics, Oxford University Press, Oxford.

Fayissa, B., Nsiah, C., and Tadasse, B. (2007), 'The impact of tourism on economic growth and development in Africa', Department of Economics and Finance Working Paper, Middle Tennessee State University, Murfreesboro, TN.

Filis, G., and Leon, C. (2006), 'The transmission mechanism of the cyclical components of the Greek output, investments and stock exchange', paper presented at 1st International Conference on Accounting and Finance, Thessaloniki, 7-8 September.

Filis, G., Floros, C., Leon, C., and Beneki, C. (2010), 'Are EU and Bulgarian business cycles synchronized?', Journal of Money, Investment and Banking, Vol 14, pp 36-45.

Gani, A. (1998), 'Macroeconomic determinants of growth in the South Pacific island economies', Applied Economics Letters, Vol 5, pp 747-749.

Gouveia, P., and Rodrigues, P. (2005), 'Dating and synchronizing tourism growth cycles', Tourism Economics, Vol 11, No 4, pp 501-515.

Granger, C.W.J., and Hatanaka, M. (1964), Spectral Analysis of Economic Time Series, Princeton University Press, Princeton, NJ.

Granger, C.W.J., and Watson, M.W. (1984), 'Time series and spectral methods in econometrics', in Handbook of Econometrics, Volume II, North Holland and Elsevier Science, New York, pp 9801022.

Guizzardi, A. and Mazzocchi, M. (2010), 'Tourism demand for Italy and the business cycle', Tourism Management, Vol 31, No 3, pp 367-377. 
Gunduz, L., and Hatemi-J, A. (2005), 'Is the tourism-led growth hypothesis valid for Turkey?', Applied Economics Letters, Vol 12, pp 499-504.

Harding, D., and Pagan, A. (2003), 'A comparison of two business cycle dating methods', Journal of Economics \& Control, Vol 27, No 9, pp 1681-1690.

Harris, R. (1995), Using Cointegration Analysis in Econometric Modelling, Prentice Hall/Harvester Wheatsheaf, London.

Hazari, B., and Sgro, P. (1995), 'Tourism and growth in a dynamic model of trade', Journal of International Trade and Economic Development, Vol 4, pp 253-256.

Hellenic Republic, Ministry of Economy and Finance (2006), Fact Sheet on the Prospects of the Greek Economy, Ministry of Economy and Finance, Athens, March.

Helpman, E., and Krugman, P. (1985), Market Structure and Foreign Trade, MIT Press, Cambridge, MA.

Hodrick, R., and Prescott, E. (1997), 'Postwar US business cycles: an empirical investigation', Journal of Money, Credit and Banking, Vol 29, pp 1-16.

Iacobucci, A. (2003), 'Spectral analysis for economic time series', Working Paper No 2003-07, Observatoire Français des Conjonctures Economiques (OFCE), Sciences Po, Paris.

Inklaar, R., and de Haan, J. (2001), 'Is there really a European business cycle? A comment', Oxford Economic Papers, Vol 53, No 2, pp 215-220.

Jenkins, G., and Watts, D. (1968), Spectral Analysis and its Applications, Holden-Day London.

Johansen, S. (1988), 'Statistical analysis of cointegration vectors', Journal of Economic Dynamic and Control, Vol 12, pp 231-254.

Johansen, S., and Juselius, K. (1990), 'Maximum likelihood estimation and inference on cointegration: with applications to the demand of money', Oxford Bulletin of Economics and Statistics, Vol 52, pp 169-210.

Johansen, S., and Juselius, K. (1992), 'Testing structural hypothesis in a multivariate cointegration analysis in PPP and the UIP for UK', Journal of Econometrics, Vol 53, pP 169-209.

Johansen, S., and Juselius, K. (1994), 'Identification of the long-run and the short-run structure an application of the ISLM model', Journal of Econometrics, Vol 63, pp 7-36.

Katircioglu, S.T. (2009), 'Revisiting the tourism-led-growth hypothesis for Turkey using the bounds test and Johansen approach for cointegration', Tourism Management, Vol 30, pp 17-20.

Khan, H., Phang, S., and Toh, R. (1995), 'The multiplier effect: Singapore's hospitality industry', Cornell Hotel and Restaurant Administration Quarterly, Vol 36, pp 64-69.

Khan, H., Seng, C.F., and Cheong, W.K. (1990), 'Tourism multiplier effects on Singapore', Annals of Tourism Research, Vol 17, No 3, pp 408-418.

Kim, H.J., Chen, M-H., and Jang, 'Shawn' S.C. (2006), 'Tourism Expansion and economic development: the case of Taiwan', Tourism Management, Vol 27, pp 925-933.

Krueger, A. (1980), 'Trade policy as input to development', American Economic Review, Vol 70, pp 188-292.

Lanza, A., and Pigliaru, F. (2000), 'Why are tourism countries small and fast growing?', in A. Fossati and G. Panella, eds, Tourism and Sustainable Economic Development, Kluwer, Dordrecht, pp 57-69.

Lanza, A., Temple, P., and Urga, G. (2003), 'The implications of tourism specification in the longrun: an econometric analysis for 13 OECD economies', Tourism Management, Vol 24, pp 315-321.

Lee, C., and Kwon, K. (1995), 'Importance of secondary impact of foreign tourism receipts on the South Korean economy', Journal of Travel Research, Vol 34, pp 50-54.

Lee, C.C., and Chang, C.P. (2008), 'Tourism development and economic growth: a closer look at panels', Tourism Management, Vol 29, No 1, pp 180-192.

Leon, C., and Eeckels, B. (2009), 'A dynamic correlation approach of the Swiss tourism income', Munich Personal RePEc Archive, No 15215.

Louca, C. (2006), 'Income and expenditure in the tourism industry: time series evidence from Cyprus' Tourism Economics, Vol 12, No 4, pp 603-617.

Marin, D. (1992), 'Is the export-led hypothesis valid for industrialized countries?', Review of Economics and Statistics, Vol 74, pp 678-688.

Mc Kinnon, R. (1964), 'Foreign exchange constraints in economic development and efficient aid allocation', Economic Journal, Vol 74, pp 388-409.

Narayan, P.K. (2004), 'Economic impact of tourism on Fiji's economy: empirical evidence from the computable general equilibrium model', Tourism Economics, Vol 10, No 4, pp 419-433.

Noriko, I., and Mototsugu, F. (2007), 'Impacts of tourism and fiscal expenditure to remote islands: the case of the Amami islands in Japan', Applied Economics Letter, Vol 14, pp 661-666. 
Nowak, J.J., Sahli, M., and Cortés-Jiménez, I. (2007), 'Tourism, capital good imports and economic growth: theory and evidence for Spain', Tourism Economics, Vol 13, No 4, pp 515-536.

Oh, C.O. (2005), 'The contribution of tourism development to economic growth in the Korean economy', Tourism Management, Vol 26, pp 39-44.

Page, S. (1999), "Tourism and development: the evidence from Mauritius, South Africa and Zimbabwe', Internal ODI Working Paper, Overseas Development Institute, London.

Papanikos, G. (2005), Greek Tourism Receipts, Special Report No 5, Research Institute of Tourism, Athens (in Greek).

Pavlopoulos, P. (1999), The Size and Dynamic of the Tourism Sector, Research Institute for Tourism, Athens (in Greek).

Rudebusch, G.D., and Svensson, E.O.L. (1999), 'Policy rules for inflation targeting', in Taylor, B.J., ed, Monetary Policy Rules, Chicago University Press, Chicago, IL, pp 203-246.

Shan, J., and Wilson, K. (2001), 'Causality between trade and tourism: empirical evidence from China', Applied Economics Letters, Vol 8, pp 239-83.

Sharpley, R., and Telfer, D. (2002), Tourism and Development: Concepts and Issues, Channel View, Clevedon.

Song, H. and Li, G. (2008), 'Tourism demand modelling and forecasting: a review of recent research', Tourism Management, Vol 29, No 2, pp 203-220.

Soukiazis, E., and Proença, S. (2008), 'Tourism as an alternative source of regional growth in Portugal: a panel data analysis at NUTS II and III levels', Portuguese Economic Journal, Vol 7, No 1, pp 43-61.

Sugiyarto, G., Blake, A., and Sinclair, M.T. (2002), Economic Impact of Tourism and Globalization in Indonesia, Christel Del Haan Tourism and Travel Research Institute, Nottingham University Business School, Nottingham.

Sugiyarto, G., Blake, A., and Sinclair, T. (2003), 'Tourism and globalization: economic impact in Indonesia', Annals of Tourism Research, Vol 30, No 3, pp 683-702.

Thalassinos, E. (1991), Time Series Analysis, Stamoulis Publishings, Piraeus (in Greek).

Uysal, M., and Gitelson, R. (1994), 'Assessment of economic impacts: festivals and special events', Festival Management and Event Tourism, Vol 2, No 1, pp 3-10.

Vanegas, M., and Croes, R. (2003), 'Growth, development and tourism in a small economy: evidence from Aruba', International Journal of Tourism Research, Vol 5, pp 315-330.

Varelas, E., and Kaskarelis, I. (1996), Stylized Facts and Macroeconomic Models for the Post-War Greece, 1960-1990, Agricultural Bank of Greece, Athens (in Greek).

West, G.R. (1993), 'Economic significance of tourism in Queensland', Annals of Tourism Research, Vol 20, No 3, pp 490-504.

Wong, K.K.F. (1997), 'The relevance of business cycles in forecasting international tourist arrivals', Tourism Management, Vol 18, No 8, pp 581-586.

Wyer, L., Forsyth, P., and Spurr, R. (2003), 'Inter-industry effects of tourism growth: implications for destination managers', Tourism Economics, Vol 9, No 2, pp 117-132.

Zortuk, M. (2009), 'Economic impact of tourism on Turkey's economy: evidence from cointegration tests', International Research Journal of Finance and Economics, Vol 25, pp 231-239. 